\title{
Running Wild: engaging and empowering future custodians of place through creative nature-based play
}

Tanja Beer, Andrea Cook and Kate Kantor

\author{
University of Melbourne
}

\begin{abstract}
Children are spending significantly less time in nature than ever before. The decline in nature-based play has been precipitated by many factors, including: increased risk aversion and fear amongst parents, poor play opportunities for children and the rapid embrace of digital technology as recreation by young people. These factors all contribute to a collective and individual loss of childhood experience with nature. At the same time, young people are increasingly aware of the unprecedented level of climate change, pollution, habitat destruction and species extinction and the effect it could have on their futures. Thus, there is an urgent need for new approaches to environmental learning that celebrates children's agency, supporting them to directly contribute to ecological systems and global sustainability across communities. This paper explores the potential of creative nature-based play to contribute to children's identity and understanding of the natural world through a practice-led research project, Running Wild (2016). Running Wild was conducted with Polyglot Theatre in collaboration with Year 6 students from Mahogany Rise Primary School (Frankston North) and the Royal Botanic Gardens (Cranbourne). The aim of the project was to introduce the students to their natural reserve ('The Pines') through participatory art-making in collaboration with local artists, scientists and Indigenous elders. This included the opportunity for children to build their own habitats or 'cubbies', make animal costumes and plant native seedlings at The Pines, resulting in an outdoor performance for their families and friends. Running Wild not only demonstrated increased nature-connection amongst the students, but also the importance of creative nature-based play in improving learning capacities and wellbeing, as well as promoting opportunities for environmental leadership.
\end{abstract}

\section{Keywords}

children; nature; arts-science; play; urban environments; sustainability

Journal of Public Pedagogies, Number 3, 2018

Published by Public Pedagogies Institute: www.publicpedagogies.org

Open Access article distributed under a CC-BY-NC 4.0 license

URL http://jpp.vu.edu.au/

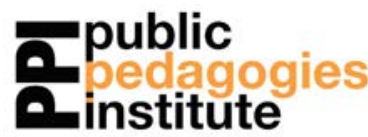




\section{Introduction}

Children are spending significantly less time outside and in nature than ever before (Louv 2008). Over the last 30 years, there has been a steady decline in children's independent play (including nature play), both in Australia and globally (Hillman et al 1990; Lee et al 2015; Freeman \& Tranter 2011). This decline has been precipitated by many factors, including: increased risk aversion and fear amongst parents (Freeman \& Tranter 2011; Malone 2007), poor play opportunities for children (Kyttä 2004; Beunderman et al 2007), and the rapid embrace of digital technology as recreation by young people (Yang et al 2017). These factors all contribute to a collective and individual loss of childhood experience with nature. The implications of these losses are being calculated by researchers in a range of areas, with loss of independent play and mobility implicated in worsening health outcomes for children (e.g. increased obesity rates and related diseases such as type 2 diabetes) (Schoeppe et al 2014), declining spatial acuity in children (Sobel 1998), eroding environmental values and sense of 'place' (Timperio et al 2004) and concerns about the abilities of children to develop and deploy civic agency over their environments, now and into the future (Cook 2016; Cockburn 2005).

At the same time, young people are increasingly aware of the unprecedented level of climate change, pollution, habitat destruction and species extinction and the effect it could have on their futures (Pronczuk \& Surdu 2008). Where children once widely experienced ecophilia-a love of nature-that lasted into and shaped, adulthood environmental preferences (Cooper Marcus 1978), contemporary children are increasingly experiencing 'ecophobia'-a paralysing fear of environmental destruction (Sobel 1998; Strife 2012). With it comes an increased sense of disempowerment and despair, amongst children, regarding their future and their abilities to shape that future (Green 2013). Children's lack of ecological connection and sense of powerlessness about the future (Wilks 2010) has created an urgent need for new approaches to environmental custodianship that celebrate children's agency.

This paper explores the potential of creative nature-based play in contributing to children's identity and understanding of their natural environments through a practice-led research project (Running Wild, 2016). Running Wild was conducted with Polyglot Theatre in collaboration with Year Six students from Mahogany Rise Primary School (Frankston North) and the Royal Botanic Gardens, Cranbourne. The aim of the project was to introduce the children to their natural reserve ('The Pines') through participatory art-making in collaboration with local artists, ecologists and Indigenous elders. This involved inviting the children to become co-designers in building habitats ('cubbies'), making animal costumes and planting native seedlings - resulting in an outdoor performance and exhibition for their families and friends.

In this paper, we define 'nature' as a series of interconnected ecological relationships, of which humans are a part, rather than a separate entity that exists outside or separate to ourselves. Nevertheless, we also acknowledge that the concept of 'nature' can be ambiguous and can result in a variety of understandings for different people.

Our project aims were fourfold: 1) To investigate new approaches to environmental education that celebrate children's agency and hope for the future; 2 ) to explore the potential of creative nature-based play to contribute to children's identity and understanding of their natural environments; 3) to use creative nature-based play to help enable children's instinctive connection with nature; and 4) to support children's agency within their own environments now and into the future. 
The paper builds on the argument that children have a fundamental right to participate in the debate about the future of the environment, employing their social agency as citizens (Cook 2016; Cockburn 2005; Beunderman et al 2007). We examine the potential of the 'agentic child' (a capable and competent social actor who co-creates with other children and adults) to positively contribute to their environments (Marr \& Malone 2007; Cook \& Beer 2018). Our aim is to demonstrate ways in which children can express their ideas for positive transformation (Somerville \& Green 2015; Pratt 2009) and actively contribute to their local neighbourhood.

\section{Rekindling children's environmental values and love of nature}

While the benefits of children 'being in' nature are now well known (Louv 2008), there is little research regarding how children develop environmental values, including attachment to nature and a "deep and lasting concern" for the environment. Hart suggests that this question is central to the widely held belief that a concerned and informed citizenry is critical to stewardship of the environment (Hart 1997, p. 17-26). Scholarship on place attachment-"people's bonding with meaningful spaces" (Milhaylov \& Perkins 2014, p. 61) -may help us frame an understanding of how environmental values form in childhood.

In the 1970s, Clare Cooper Marcus' work on 'environmental autobiographies'-adult reflections on childhood experiences of space and their role/s in shaping environmental preferences and values-illustrated the primacy of nature in people's place attachments. Across countries of upbringing, culture, gender and socio-economic backgrounds, there were two elements that consistently featured in people's reflections on ideal childhood environments: nature or outdoor environments, and places that children hid away from adults (Cooper Marcus 1978). Both elements reflect a kind of freedom: freedom from the rules of the house (e.g. don't make a mess), freedom from parental control, freedom to adventure and explore and freedom to test oneself against the world and be challenged by the unknown. Such exercises in freedom are also exercises in agency. Both combine to provide a child's (independent) love of nature, or 'ecophilia'.

Since the 1970s, however, there have been very sharp declines in children's independent play and mobility, both in Australia and globally. Increasingly, children's experiences of their world are from the back seat of the family car (Cook 2016; Malone 2007). Environmental researchers are also seeing evidence of 'ecophobia' amongst children, both at a meta scale (e.g. children's concerns about global environmental destruction) and the micro scale (e.g. children's fears about local environments, animals, and plants) (Strife 2012). Renewed scholastic attention is emerging around the ways in which children connect to their natural environments, in large part because of these massive generational changes to children's experiences of nature. Nevertheless, not enough of this research addresses childled nature-based learning and the potential benefits of children's active contribution to place through environmental enquiry and art making.

Experiences that were 'child-driven' was ranked as the second most important quality (just behind 'engages all the senses') for a 'significant nature activity' in recent meta-analysis of human-nature connection research (Giusti et al 2018, p. 8). This and other findings of the study add to a critique of environmental sustainability research (especially amongst children) that has become overly empirical and 'disembodied' from questions such as how sustainability can be explored with children (Hill et al 2014), and the significance of children's knowledge and enactment of sustainability (Hayward 2012; Somerville \& Green 2015). 
Participatory arts that engage in environmental placemaking practices allows the public to be involved directly in regenerative processes, encouraging them to become co-creators of the future (Condoliffe, Beer and Badham, 2018; Harvie \& Lavender 2010) and is an effective strategy for sustainability learning and social change (Jickling \& Wals 2012). This research adds to a growing scholarship that explores how participatory arts can be used in teaching young people about sustainability, allowing them to directly experience their own capacity for contribution (Beer, Curtis \& Collins, 2018; Beer \& Hernandez-Santin, 2017; Beer 2017). Running Wild aimed to make a vital contribution to exploring new approaches to environmental learning that celebrated children's agency, supporting them to directly contribute to the co-creation of their own futures (Green 2016; Hes \& du Plessis 2014).

\section{Running Wild: A case study}

These pressing theoretical concerns were tested in a practice-led research project in the North Frankston area of Melbourne Australia, the case study for this article. Running Wild was a collaboration between the University of Melbourne, Polyglot Theatre, Royal Botanic Gardens Cranbourne, Parks Victoria, Linda Mullett (a Bunurong Elder from the Mornington Peninsula area) and Mahogany Rise Primary School (North Frankston). The project engaged 36 Grade six primary school students in their local ecology-the Pines Flora and Fauna Reserve (the children's local 108 hectare bushland) and the Royal Botanic Gardens in nearby Cranbourne-through participatory arts, science and indigenous culture over a period of 12 days across five weeks. Our pedagogical approach included: teaching both Western and Indigenous perspectives of ecology within the reserve; partaking in tree planting activities with the local ranger; designing a village of 'bush cubbies'; making spirit animal costumes from reclaimed materials; creating child-led 'park ranger' information tours; making a short film and creating an outdoor exhibition and performance for the children's families that took place in 'The Pines' Reserve.

\section{Context}

The North Frankston children engaged in the research live in a community context marked by high levels of socio-economic disadvantage, (Australian Bureau of Statistics 2016) and the local school involved in the research, Mahogany Rise Primary School, struggles with associated issues of school absenteeism, poor school achievement and other signs of disengagement with mainstream, traditional modes of learning. Children's time outside of school is largely unsupervised and is spent playing video games or watching television rather than playing outside. Organised sport is expensive and requires significant parent commitment and is therefore not possible for many of the families in this area.

This context for the Running Wild project reflected/reinforced the trends in declining independent play, increasing sedentary and indoor play experience and growing ecophobia discussed in the introduction. For example, the project start was characterised by strong resistance from the children to being outside in nature (e.g fear of insects, dirt and wildlife) and remarkably low fitness levels (e.g. children visibly struggling to walk in the bush for more than 15 minutes). The children also struggled with creative play (e.g. because of poor fine motor skills and inexperience with group/team/leadership settings and skill development). 


\section{Methodology}

Running Wild employed a mixed methods research methodology (Tashakkori \& Teddlie 1998) where the majority of the inquiry was developed through the implementation of the work and its practice-led reflection-in-action. Semi-structured qualitative interviews and observations were conducted with the creative collaborators, teachers and children. Data was collected via audio and video recordings, field notes, journal notation, and photographs with ethics approval received. Our primary source of data collection was conducted using Voice Lab, a dedicated, private video documentation installation tool created by Polyglot Theatre. Voice $\mathrm{Lab}^{1}$ is a unique data capture device for collecting the thoughts of children, allowing all children to voice their opinions and feelings without the presence of moderating adults or their peers. Created as a soft, serene igloo-installation that children enter alone, a computer-generated voice asks questions, driven by a concealed live performer. Voice Lab revealed a far greater insight to children's feelings than the regular interviews and was particularly useful in providing a platform for shy or marginalised children to speak up about their ideas.

\section{Supporting Children's instinctive connection to nature}

Running Wild began by introducing the primary school students to 'The Pines', a local reserve which was a 15 minute walk from the school. Resistance to being outside was prevalent amongst the group, with a notable fear of snakes and spiders and/or an aversion to dirt or physical exercise. Despite these apprehensions, most of the children began to relax and forget about their fears and aversions as soon as we ventured into the reserve.

It has been extensively argued that humans have an innate affiliation with nature due to our long history of evolution within the natural environment (Wilson 1984). Robin Moore (1997) and others (Carson, 1962; Hayward 2012; Somerville \& Green 2015) highlight how children have a particular affinity towards nature. They are 'natural naturalists'. As Valerie Andrews (1990) explains:

As a child, one has that magical capacity to move among the many eras of the earth; to see the land as an animal does; to experience the sky from the perspective of a flower or a bee; to feel the earth quiver and breathe beneath us; to know a hundred different smells of mud and listen unself-consciously to the soughing of the trees.

While there was an initial resistance to being outside on Running Wild, we were surprised at how quickly the children become more comfortable in their natural surroundings and began to embrace the bush as their newfound play space. It wasn't long before the students were begging us to stay outside longer. As some of the children exclaimed: "It's so green here...I feel free"; "It's peaceful here... away from the hustle and bustle of the street"; "I like it here. I'm an outside person!"; and "It's my home...It's my home!!".

The effort of walking and running in the bush was also difficult for some of the less fit children. Many complained about having to walk, but soon forgot about their fatigue when becoming more engaged in nature. As one child exclaimed, "I don't like walking far distances... but I got used to it after a while....I reckon it is okay being outside". The challenging health and fitness issues that these children experienced at the start of the program are typical of today's more sedentary children (Schoeppe at al 2014).

1 More information about Polyglot Theatre's Voice Lab program can be found at: https://aifs.gov.au/cfca/ sites/default/files/4._capturing_the_voices_of_children_polyglot_0.pdf 


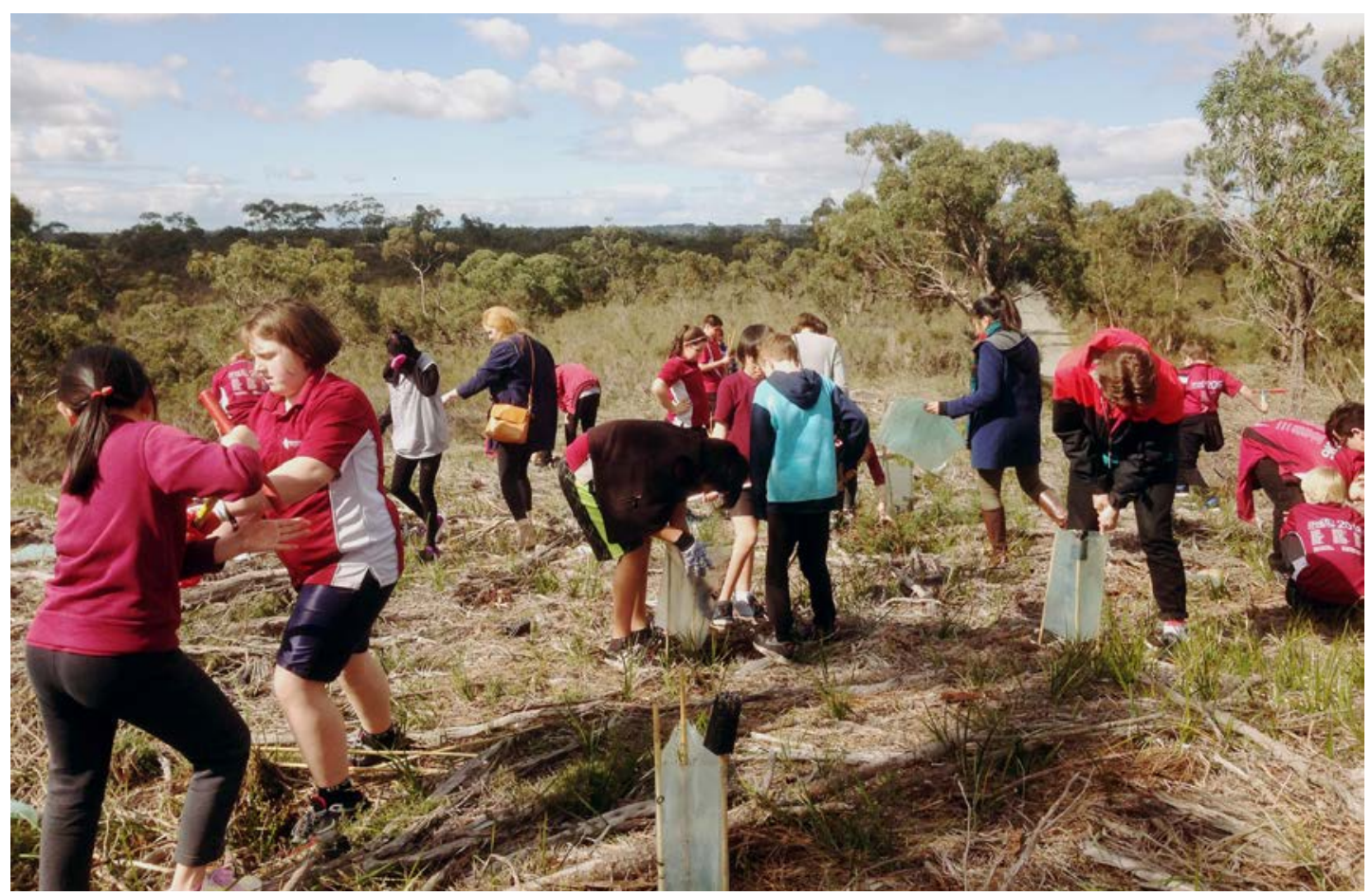

The project not only increased nature-connection, but also had a significant effect on the children's mental wellbeing as well as their learning abilities, reflecting the research of others (Louv 2008; Harris 2017; Beunderman et al 2007). The three classroom teachers that accompanied us to The Pines and the Cranbourne gardens commented on how focused and engaged the children were as a result of the nature-based workshops - including improved learning capacities and leadership qualities amongst the less academically focused students. Those that usually found it hard to stay on task in the classroom were excited and enthusiastic on the days we spent outside in nature. As one child remarked, "I learn so much better when I'm outside", and another; "[I found it] really relaxed and exciting because we got to be outside and doing stuff, instead of doing school work at school". Allowing children to exercise their instinctive connection to nature not only supports them to gain confidence in their own abilities but also their capacity to build a love and care of place (Kroencke et al 2015; Harris 2017; Lewicka 2014).

\section{Engaging with 'stories of place' through Indigenous-arts-science strategies}

A highlight of the project was our engagement with Linda Mullett, a Bunurong elder, who spent several sessions with us. Her stories and culture resonated deeply with all of the group. She accompanied us to The Pines, sharing her people's knowledge about the bush and spoke to us about the way the land was managed thousands of years ago. As we walked through the reserve, she described all the trees, plants and birds (including tiny orchids, lizards, ants and dragonflies) and their roles in the ecology of the bushland. We talked about how the southern brown bandicoot (originally living in the reserve) had disappeared due to the European introduction of foxes. The children were fascinated to learn how the strappy grass beneath their feet could be used to make baskets, the seeds from the wattle they were holding could be made into bread, the leaves from a lemon scented gum could be used to help mosquito bites and the resin for the black wattle could be a form of 'super glue' for axe construction. As one child commented, "we learnt a lot because we were outside and actually experiencing real things". 
Accompanying Linda on our walks was ecologist Richard Faulkner (a.k.a. 'Ranger Rich'). He communicated the scientific information about the flora and fauna, which he developed into a narrative focusing on the wonder and resilience of life there. He focused on habitat and biodiversity, maintaining that the bush "was like the internet", full of information and interesting links. The children were fascinated to hear how green hooded orchids acted as insects, how trees help support each other via their root system, how bowerbirds communicate with potential mates through the artistry of their bower and about the sleeping habits of koalas. Richard described the bush as a '7/11 or a milk bar' - full of food and materials for their habitats.

The children absorbed these Western and Indigenous perspectives, commenting on the usefulness of the experiences. As a one of the children explained: [I enjoyed] learning how to survive in there, if you could, and how to make things out of just plants". Or as another child admitted: "I thought it would be boring because it's just plants, but I changed my mind...And I learnt that one of the plants can be a medicine, well kind of, it can help you in many ways."

Building on our sessions with Linda and Ranger Rich, we engaged the children in art-making activities to allow them to express their responses to the information conveyed. One of these activities included 'costume-making' where the children were able to explore the idea of 'spirit animals' (a concept that Linda had discussed as part of her Indigenous culture) and create their own fantastic wearable designs, many with highly detailed stories about them and with hybrids of more than one animal.

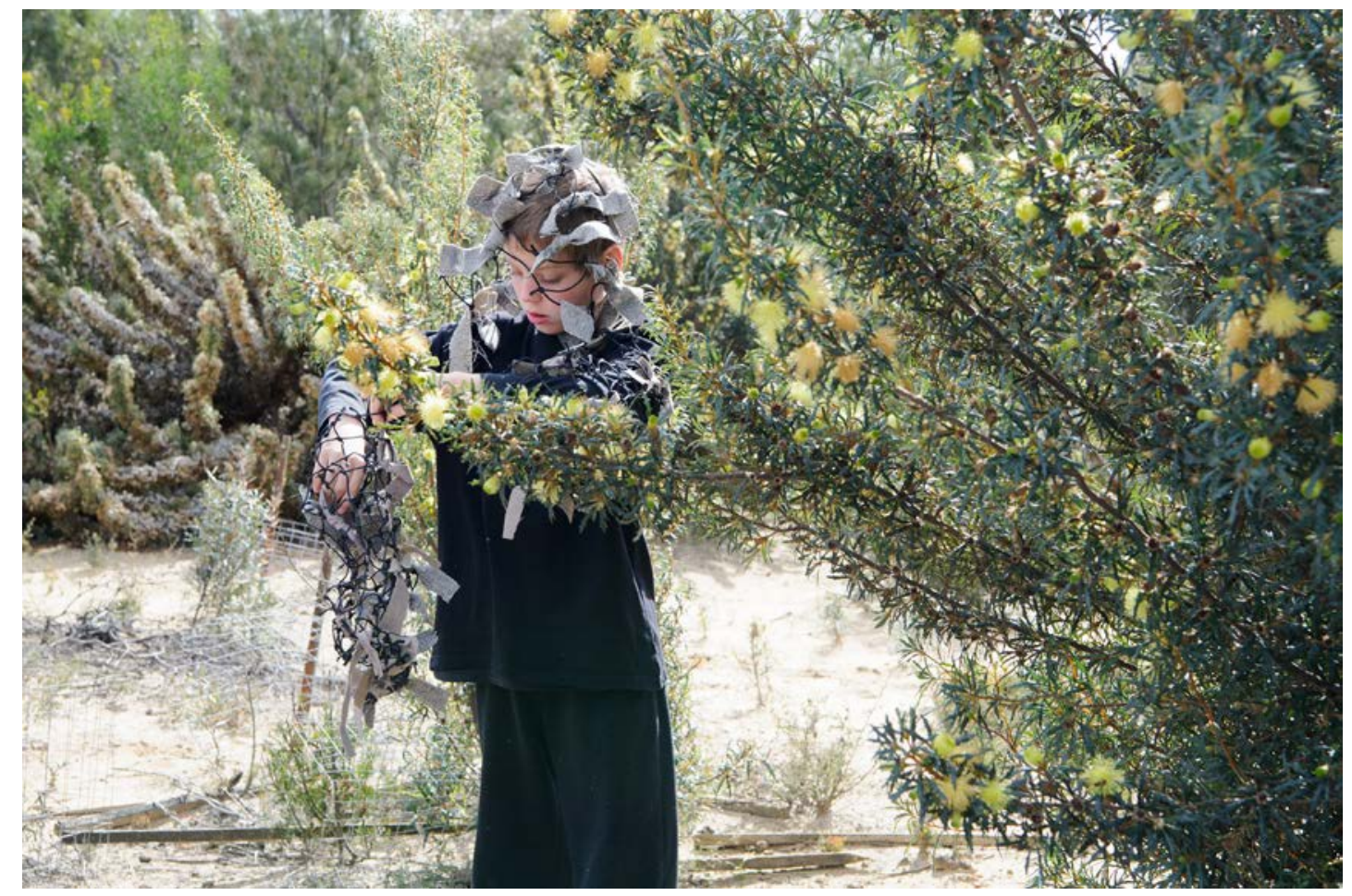

One girl made a koala with a possum's tail and eagle's wings, declaring: "I want to be able to fly, but also have a tail to swing with, and also to be able to sleep a lot!". The group was also keen focus on native animals: as one child explained, "we want ones from before the fox". This demonstrated the children's ability to synthesise their learnings of biodiversity and the importance of native species (and the fox as an invasive predator) for their local environment. 


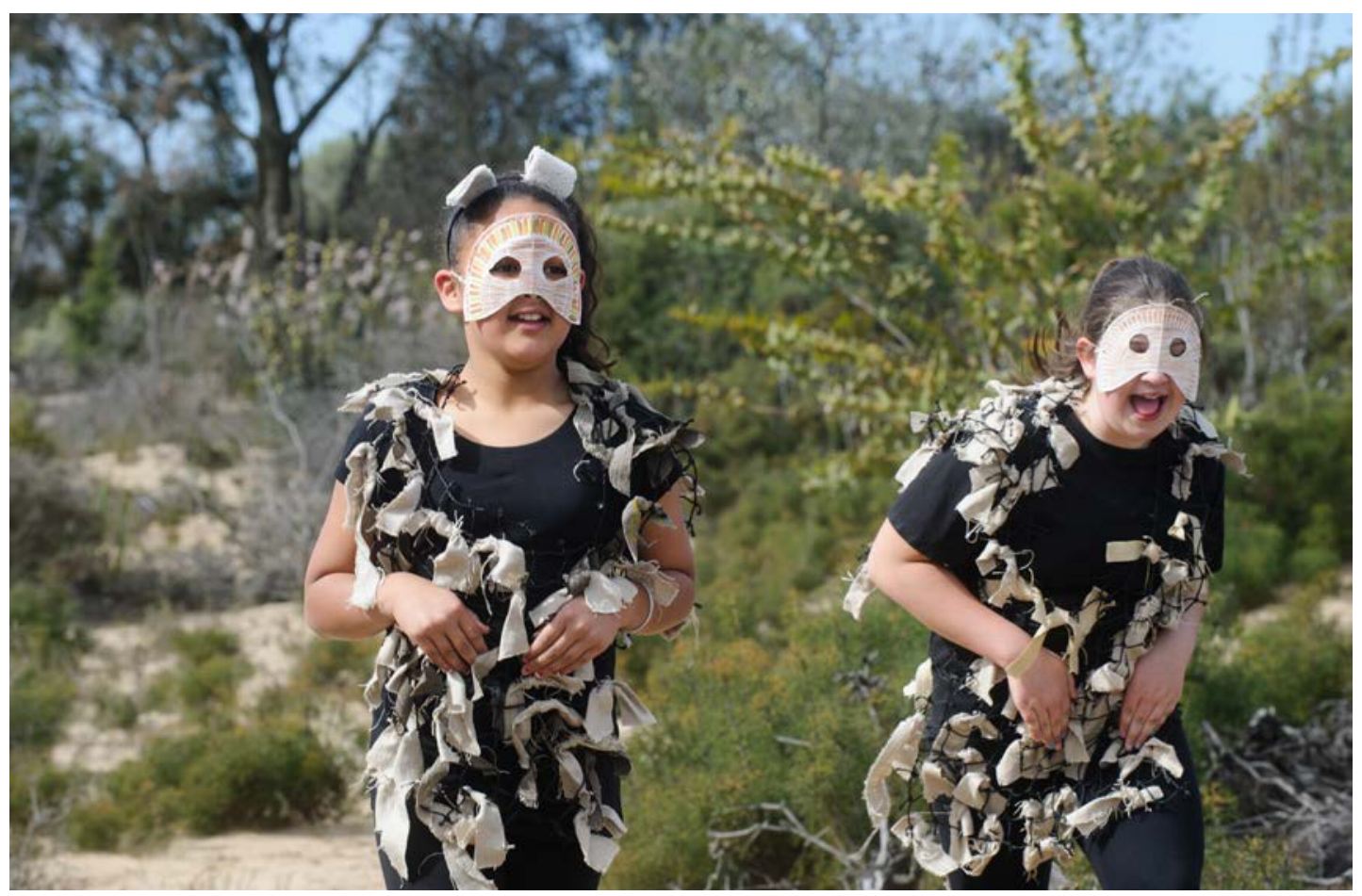

Not only did the animal costumes help the children to connect with native animals, it also allowed them to let go of their inhibitions of being in nature. Many children commented how they 'felt like an animal' when they were in their costumes. This act of intra-action, of the child and their physical dramatisation of their chosen animal, "attends to the ways that the world and child interact to produce each other as subjects-in-theworld" (Somerville \& Green 2015, p. 20). One child said "It makes me more aware of the surroundings of us and what the animals do...whole different emotions." By 'becoming animal', the children were able to enact exercises in freedom, to seek out 'wildness' and confront the unknown (Cooper Marcus 1978; Derr 2006).

Running Wild revealed the value of stories in activating ecological connection, including how imagination can permeate psycho-social spheres and influence the lives of those connected to them (Bal \& Boheemen, 2009). Stories can play a valuable role in engaging children in understanding ecological complexities, assisting to collectively deepen connections with the world around them (Beer 2017; Mang and Reed 2012, 29-30). Many weeks after we had worked with Linda and Ranger Rich, every child remembered the 'stories' of a particular plant, tree or animal that had been conveyed to them. The strength of the memory was due to the manner in which each part of the bush was related to a memorable story or feeling that could be easily related. As Rachel Carson contends:

For the child. . . it is not half so important to know as to feel. If facts are the seeds that later produce knowledge and wisdom, then the emotions and the impressions of the senses are the fertile soil in which the seeds must grow. . . . It is more important to pave the way for a child to want to know than to put him on a diet of facts that he is not ready to assimilate (1965, our emphasis).

As the children became more comfortable in The Pines through their own embodied experiences of its potential, they began to also express their capacity for agency and independence. As one child exclaimed, "I felt like I could live in nature for a while. It made me imagine what it would be like if I actually lived in our cubby for a while". This reflects 


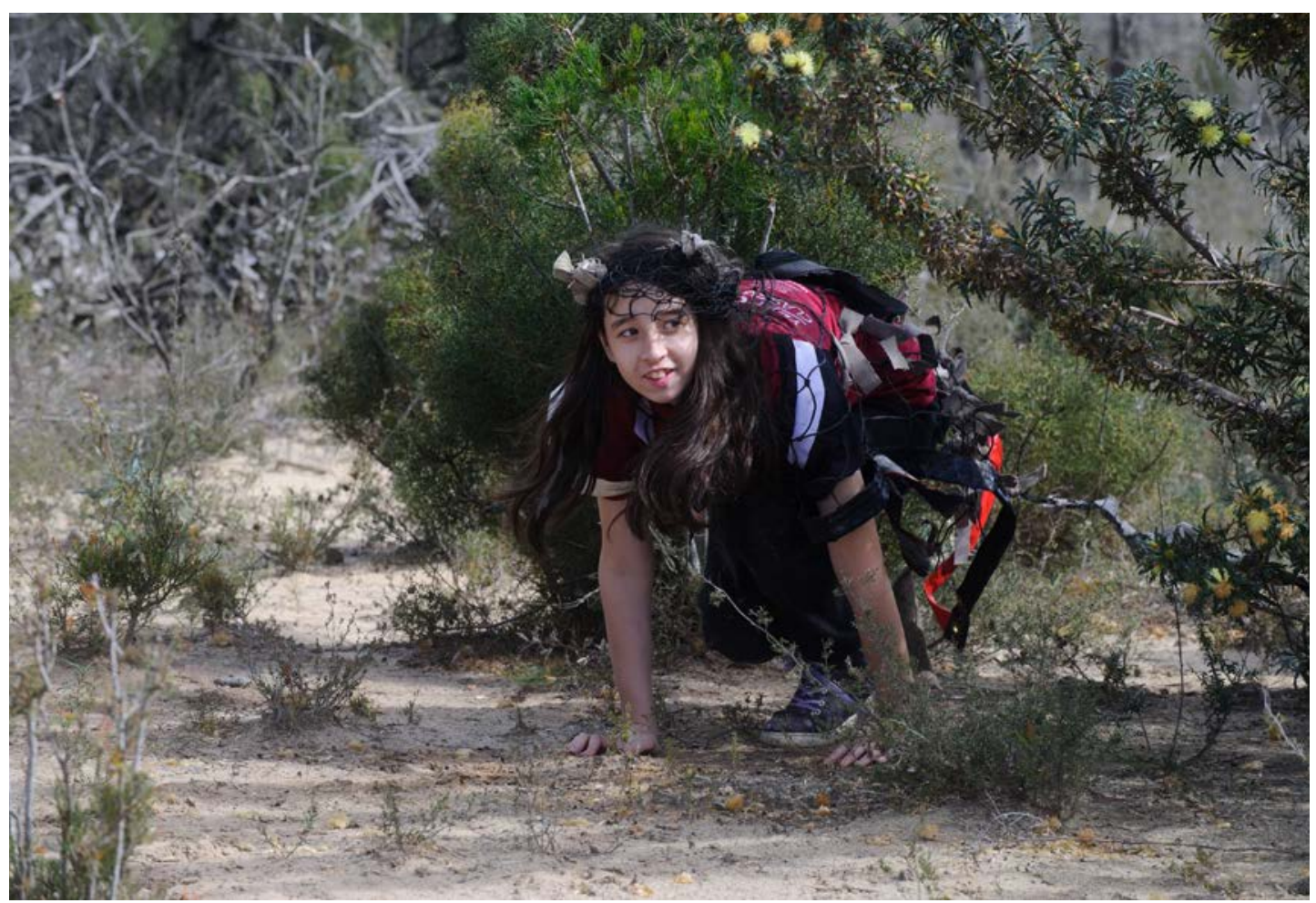

Cooper Marcus' (1978) theory that children relish the freedom to individually explore the outside world and challenge oneself and by doing so, can foster their own love of nature. A group of nine children put themselves forward to guide the public though the bush on the night of the performance, proudly telling the stories of the plants and animals to their parents and friends. Even students that usually struggled to remember facts in class were able to recite the ecology of The Pines to their parents. Carson (1962) highlights the importance of children sharing their love of nature with adults and that this relationship strengthens both parties in rediscovering "the joy, excitement, and mystery of the world we live in". The opportunity for children to become 'park rangers' and share their knowledge of The Pines was key example of allowing them to experience an enactment of environmental advocacy (Somerville \& Green 2015; Pratt 2009). This was further strengthened by the children proudly leading the planting of 75 trees and bushes with their community into an area of the reserve that needed restoration. This activity allowed them to directly experience what it meant to actively contribute to their local neighbourhood. Six children were invited to present their learnings at the national Kids Teaching Kids ${ }^{2}$ conference later that year. They attended this event as the 'environmental leaders of their school' with great pride and were able to share their experiences of the project with other young environmental leaders at the conference.

\section{Engaging in flow to foster children's agency and connection to nature}

A significant component of Running Wild was engaging the children in the experience of making cubbies ('artistic shelters' or habitats') for themselves. While we experienced some initial challenges in the children's lack of fine motor skills, designing and creating

2 The Kids Teaching Kids Program "promotes positive wellbeing and helps build resilience in young people. It raises awareness and drives action on local and global environmental issues, bringing communities together to solve common challenges and help the next generation of leaders who will take collective responsibility for our future". See: http://www.kidsteachingkids.com.au. 
cubbies was a high point for many of the group. As the children spent time exploring and fossicking for branches and leaves for the shelters, we witnessed how the act of 'making' became an important part of finding their own place in nature. As one child remarked, "I remember how we got to make cubbies and have lots of fun and be able to just do things freely and be able to like, imagine things and trying to put it into reality". This exercise in creative nature-play allowed the children to directly experience their own agency and capacity for contribution (Harvie \& Lavender 2010; Hayward 2012; Cook 2016).

The cubby-making activity facilitated experiences of 'flow', a concept developed by psychologist Mihaly Csikszentmihalyi (1990) that describes an intrinsically motivated and highly enjoyable psychological state of engagement. We observed how the children became so involved in an activity that nothing else seemed to matter - they were in the present moment' which also allowed them to foster a deeper connection to nature. As a few of the students commented, "[Making stuff] is quite fun and takes your mind of stuff... like stressful stuff"; "I had so much fun when I was building my cubbies and just learning about nature in general", and; "it made me feel at one with nature and also more open".

Flow activities lend themselves well to artistic practices that are focused on using creativity to increase intellectual and bodily cognition, focus and wellbeing (Csikszentmihalyi 1990). As one child expressed, The Pines could be "a place you can go when you need anger management or just a place you can go for fun". Once the children were deeply 'in the zone', they happily engaged in finding materials, imagining and creating 'bush homes' for their groups. They resisted when being told that it was time to go back to school. As one child remarked: "We were just getting started... and now we have to go... Not happy!".

Collaborating as a team to build the cubbies was a difficulty for many of the children due to the high level of social issues amongst the group. Despite this, many of the students expressed that 'making together' had helped them to work better with others, enabling them to gain greater social awareness, collegiality and leadership capabilities (Cook 2016; Hayward 2012). As a few of the children commented: "So working in a team...I don't really like...But I wouldn't have been able to build my cubby on my own so it was good"; "now I can do more team stuff... I'm more comfortable doing team stuff" and; "It made me feel like I could co-operate much better than I did before that".

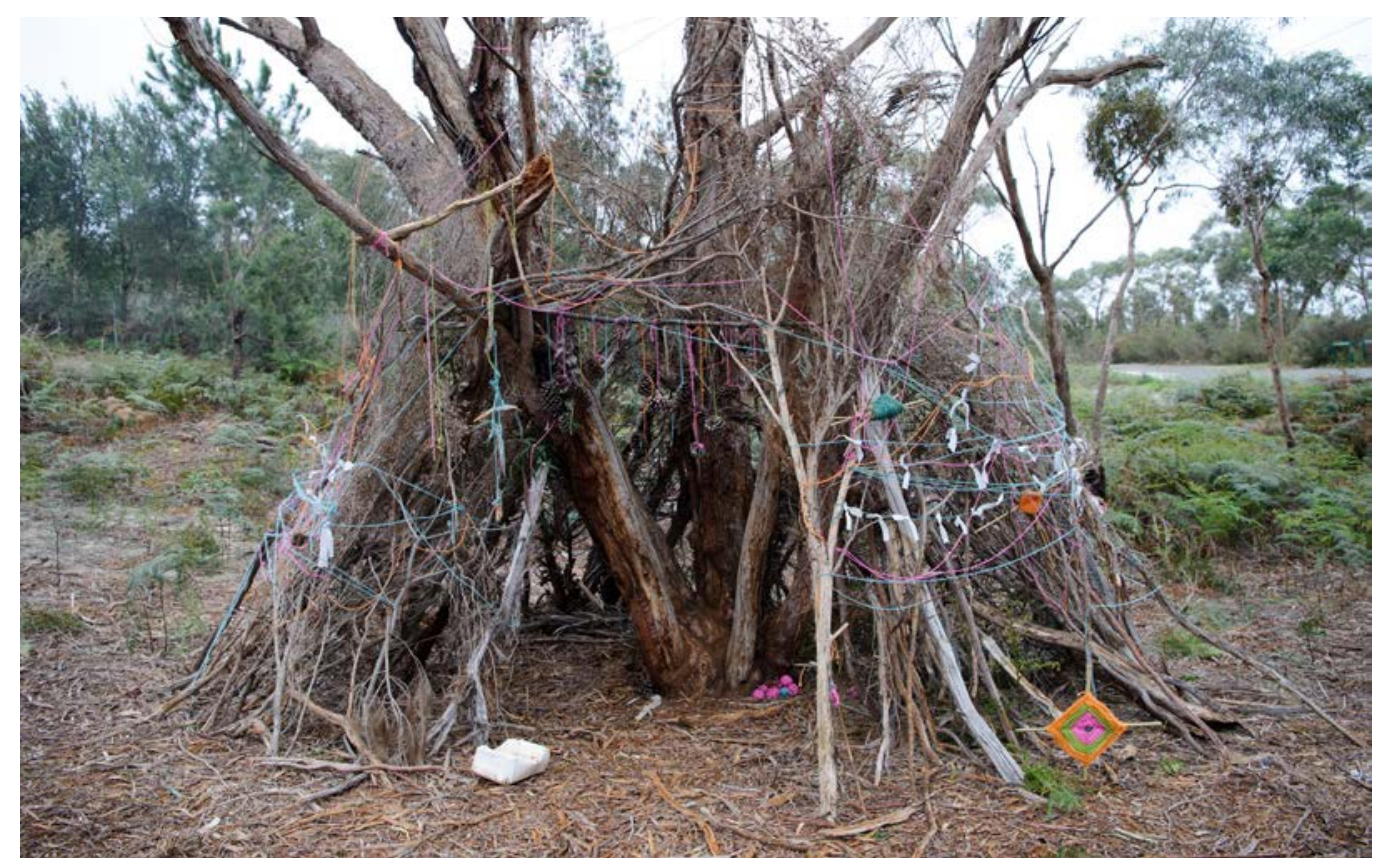


As key characteristics of flow include increased concentration; a greater integration of action and awareness; loss of self-consciousness; improved sense of control; altered sense of time; and an appreciation for activities that are intrinsically rewarding ( $\mathrm{Na}$ kamura \& Csikszentmihalyi 2002: 90), it was no surprise that the children to become more socially perceptive and more engaged in their surroundings as a result (Seligman 2002; Kaplan 2000).

\section{Conclusion}

Running Wild demonstrated the key qualities framed by Giusti et al (2018) in their meta-analysis of qualities needed for 'significant nature activity': it was entertaining, provided environmental epiphanies, it was restorative, focused on education but also on free play and engaged with plants and animals. In particular, it demonstrated the power of child-driven, challenging, physical and cultural/artistic activity in shaping connection to nature amongst children, their families and their community.

The project revealed how participatory arts and in particular, creative nature-based play using Indigenous-arts-science strategies could increase children's connection to nature and encourage young people to have agency within their local environments. A key discovery was the importance of supporting children's instinctive connection to nature and nurturing young people's authentic interest in the environment, to help advocate for its future. As one child reflected, "it made me feel more gratitude to nature and it made me feel more protective of nature and stuff". Many children also mentioned their new found connection and enthusiasm for The Pines and expressed an interest in returning after the project. As a couple of children commented. "[the Pines] is full of flora, fauna and life. I will go more often than I have been before"; "it changed my mind because I had never been to The Pines before", and; "I would go there again to have fun and explore".

Running Wild demonstrates the value of creative nature-based play in allowing young people to freely engage in their local environments, with each other and with the wider community. Using multiple engagement activities (such as cubby building, making animal costumes, etc.) allows children to independently find their own ways of understanding and appreciating nature and conveying that new appreciation to others. As one child exclaimed, "it made me kind of realise that I need to be outside more and be outside in the nature and I need to explore more, because there's so much out there that's unexplored and I thought maybe I could go out there and do some exploring of my own". These findings support and add to the body of emerging research that explores how creative nature-based play can support children in understanding and build empathy for nature (Harris 2017; Hayward 2012; Sobel 2008). There is also scope to link this co-learned sustainability work to the growing literature on children's citizenship, a hitherto under-explored area within the civil rights and agency literatures (Cook 2016; Hayward 2012; Cockburn 2005). Future research might experiment further with child-led and child-designed methodology, for example.

Running Wild has generated case study and methods advice for others interested in practice-led research in this area. A key significance of the Running Wild research lies in its simplicity and, hence, its transferability to other settings, both in Australia and internationally. With relatively simple materials and access to some natural outdoor space, the methods of this research can be replicated (and, indeed, built upon and enhanced) elsewhere. These approaches and methods, additionally, are relevant in both research and practice settings, reflecting the applicability of public pedagogies to environmental sustainability. 
As we move towards a future of increasing environmental challenges, the need to involve our next generation in appreciating and respecting the natural world is of pressing significance. At the same time, children's enthusiasm for nature can also act as valuable tool in reminding adults of the importance of the outside world for learning and connection (Moore, 1997). Running Wild has illustrated how local communities can enact some simple (yet profound) techniques to reconnect children with nature and with their own 'inborn sense of wonder' (Carson 1962). Such arts-science practices have the promise of not simply teaching children about the flora and fauna around them but also seeding important civic/agentic skills that will enable the next generation to be effective advocates for a positive environmental future.

\section{References}

Andrews, V 1990, A passion for this earth: exploring a new partnership of man, woman, \& nature, San Francisco, Harper.

Australian Bureau of Statistics, 2016, Census of Population and Housing: Socio-Economic Indexes for Areas (SEIFA) Australia, http://www.abs.gov.au/AUSSTATS/abs@.nsf/ DetailsPage/2033.0.55.0012016? OpenDocument, accessed 22/06/18.

Ayers, W 2017, Teaching toward Democracy: Educators as Agents of Change, Routledge, New York.

Bal, M \& van Boheemen, 2009, Narratology: Introduction to the Theory of Narrative, Toronto, University of Toronto Press.

Beunderman, J, Hannon, C \& Bradwell, P 2007, Seen and Heard: Reclaiming the Public Realm with Children and Young People, Demos, London.

Beer, T, Curtis, D \& Collins J 2018, "Innovation: Creativity as a Renewable Resource for the Eco-City", In Enabling Eco-Cities: Defining, Planning, and Creating a More Thriving Future, Edited by Dominique Hes and Judy Bush, Palgrave Pivot, pp. 2142.

Beer, T \& Hernandez-Santin C, 2017, "Refugium WA: crafting connection through plant-relating arts-science experiences of urban ecology", Nordic Journal of Science and Technology Studies 5, no. 2, pp. 30-43.

Beer, T 2017, "The Boy and the Sunflower: the role of theatre in communicating ecological processes through the creation of living stages", in Building Sustainability with the Arts: Proceedings of the 2nd National EcoArts Australis Conference, in Curtis, D (ed.), Newcastle upon Tyne, Cambridge Scholars Publishing.

Bishop, C 2012, Artificial Hells: Participatory Art and the Politics of Spectatorship, Verso, London.

Carson, R, 1962, Silent Spring, London: Penguin.

Carson, R, \& Pratt, C 1965, The Sense OfWonder, New York, Harper \& Row.

Christensen, P \& Allison, J 2000, Research with Children: Perspectives and Practices, Routledge, Oxon. 
Cockburn, T 2005, 'Children as participative citizens: a radical pluralist case for 'childfriendly' public communication', Journal of Social Sciences, Special Issue 9, pp19-29.

Condoliffe, Z, Beer, T and Badham, M, 2018, "Refugium at Federation Square: the politics of participatory ecological artwork in public-private space", Global Performance Studies Journal 1, no.2.

Cook, A \& Beer, T 2018, 'Planting Citizenship: Lessons for Invoking Sustainability via Children's Civic Voice', Architecture MPS Conference Proceedings

Cook, A 2016, 'Children's citizenship', in Freeman, C. and Tranter, P. (eds.) Risk, Protection, Provision and Policy, Vol. 12 of Skelton, T. (ed.) Geographies of Children and Young People, Springer, Singapore.

Cooper Marcus, C 1976, 'Children and their environments: A review of research 19551975 (and a discussion of why the findings have been largely ignored)', Journal of Architectural Education, Vol. 29, No. 4, pp 22-25.

Cooper Marcus, C 1978, 'Remembrance of landscape past', Landscape, Vol. 22, No. 3 , pp 35-43.

Csikszentmihalyi, M 1990, Flow: the psychology of optimal experience, Harper and Row, New York.

Derr, T 2006, 'Sometimes a bird sounds like a fish: Perspectives on children's place experience' in Spencer, C., \& and Blades, M. (eds.), Children and their environments: Learning, using and designing spaces, pp. 108-123, Cambridge University Press, Cambridge UK.

Freeman, C \& Tranter, P 2011, Children and their Urban Environments: Changing worlds, Earthscan, London.

Green, M 2016, 'If there's no sustainability our future will get wrecked: Exploring Children's Perspectives of Sustainability' in Childhood, Vol 24 Issue 2, pp151-167.

Green, M 2013, 'Transformational design literacies: children as active place-makers,' Children's Geographies, Vol 11 No 4, pp1-16.

Giusti M, Svane U, Raymond C M \& Beery TH 2018, 'A Framework to Assess Where and How Children Connect to Nature', Frontiers in Psychology, Vol. 8, Article 2283.

Harris, F 2017, 'The Nature of Learning at Forest School: Practitioners' Perspectives', Education 3-13, Vol. 45, No. 2, pp. 272-291.

Hart, RA 1997, Children's participation: The theory and practice of involving young citizens in community development and environmental care, Earthscan, London UK.

Harvie, J \& Lavender, A 2010, Making Contemporary Theatre, Manchester University Press, Manchester.

Hayward, B 2012, Children, Citizenship and Environment, Routledge, Oxon.

Hes, D \& du Plessis, C 2014, Designing for Hope: Pathways to Regenerative Sustainability, Taylor and Francis, Hoboken.

Hill, A, McCrea, N, Emery, S, Nailon, D, David, JM, Dymnet JE \& Getenet, S 2014, 'Exploring how adults who work with young children conceptualise sustainability and 
describe their practice initiatives', Australian Journal of Early Childhood, Vol 39 No 3, pp14-22.

Holloway, SL \& Valentine, G (eds) 2000, Children's Geographies, Routledge, Oxon.

Jickling, B \& Wals, AE 2012, 'Debating education for sustainable development 20 years after Rio: a conversation between Bob Jickling and Arjen Wals', Journal of Education for Sustainable Development, Vol 6 No 1, pp 49-57.

Kaplan, Frances, 1999, Art Science and Art Therapy, London, Jessica Kingsley Publishers.

Kroencke, RD, Hoormann, KA, Beyer, KM, Heller, EF, Bizub, JM \& Zetts, CJ, 2015, 'Knowledge of Neighborhood Nature is Associated with Strong Sense of Place among Milwaukee Youth', Children, Youth \& Environments, Vol. 25 Issue 3, pp.129-144.

Kyttä, M, 2004, 'The extent of children's independent mobility and the number of actualized affordances as criteria for child-friendly environments', Journal of Environmental Psychology, Vol. 24, pp 179-198.

Lee, H., Tamminen, KA, Clark, AM, Slater, L, Spence, JC, \& Holt, NL 2015, 'A metastudy of qualitative research examining determinants of children's independent active free play', International Journal of Behavioral Nutrition and Physical Activity, Vol. 12, No. 5, pp 1-12.

Lewicka, M 2014, 'In search of roots: Memory and an enabler of place attachment' in Manzo, L. C., \& Devine-Wright, P. (eds.), Place attachment: Advances in theory, methods and practice, Routledge, London, pp. 49-60.

Louv, R 2008, Last Child in the Woods: Saving our Children from Nature-deficit Disorder, 2nd edn, Books of Chapel Hill, Algonquin.

Malone, K 2013, 'The future lies in our hands: children as researchers and environmental change agents in designing a child-friendly neighbourhood', The International Journal of Justice and Sustainability, Vol 18 No 3, pp 372-395.

Mang, Pamela, and Bill Reed, 2012, "Designing from Place: A Regenerative Framework and Methodology”, Building Research \& Information, Vol 40 No 1, pp 23-38.

Marr, P \& Malone, K 2007, What About Me? Children as Co-researchers, University of Wollongong, Wollongong.

Moore, Robin C, 1997, Natural learning: the life history of an environmental schoolyard: creating environments for rediscovering nature's way of teaching, Berkeley, California, MIG Communications.

Nakamura, J \& Csikszentmihalyi M 2009, “The concept of flow.” In Furlong M J., Gilman R, and Huebner S (eds.), Handbook of positive psychology, Hoboken, Taylor and Francis, pp 89-105.

Pratt, R 2009, 'Practical possibilities and pedagogical approaches for early childhood education for sustainability' in Davis, J (ed.), Young children and the environment: Early education for sustainability, Cambridge University Press, Port Melbourne, Victoria, pp.104-153.

Pronczuk, J \& Surdu, S 2008, Children's environmental health in the twenty-first century, Annals of the New York Academy of Sciences, Vol 1140, p.143. 
Schoeppe, S, Duncan, MJ, Badland, HM, Oliver, M, \& Browne, M 2014, 'Associations between children's independent mobility and physical activity', BMC Public Health, Vol. 14, No. 1, pp. 1-18.

Sobel, D 2008, Childhood and nature: Design principles for educators, Stenhouse Publishers, Portland USA.

Sobel, D 1998, Mapmaking with children: Sense of place education for the elementary years, Heinemann, Portsmouth, USA.

Sobel, D 1996, Beyond Ecophobia: Reclaiming the Heart in Nature Education, The Orion Society, Great Barrington, Massachusetts.

Somerville, M \& Green, M 2015, Children, Place and Sustainability, PalgraveMacMillan, Basingstoke, Hampshire.

Seligman, Martin E P 2002, Authentic happiness: using the new positive psychology to realize your potential for lasting fulfilment, New York, Simon \& Schuster.

Spencer, CP \& Blades M 2006, Children and their Environments: Learning, Using and Designing spaces, Cambridge University Press, New York.

Strife, SJ 2012, 'Children's environmental concerns: Expressing ecophobia', The Journal of Environmental Education, Vol 43 No 1, pp 37-54.

Tashakkori, A \& Teddlie, C 1998, Mixed Methodology: Combining Qualitative and Quantitative Approaches, Sage, Thousand Oaks.

Timperio, A, Crawford, D, Telford, A, \& Salmon, J 2004, 'Perceptions about the local neighborhood and walking and cycling among children', Preventive Medicine, Vol. 38, pp. 39-47.

Wilks, J 2010, Child-friendly cities: a place for active citizenship in geographical and environmental education, International Research in Geographical and Environmental Education, Vol 19, No 1, pp 25-38.

Wilson, Edward O 1984, Biophilia, Harvard university press, Cambridge, Massachusetts.

Yang, F, Helgason, A, Sigfusdottir, I, Kristjansson, A 2013, 'Electronic screen use and mental wellbeing of 10-12 year old children', European Journal of Public Health, Vol 23 No 3, pp 492-498. 